\title{
Correction to: Harmonised projections of future forest resources in Europe
}

Jari Vauhkonen ${ }^{1} \cdot$ Ambros Berger $^{2} \cdot$ Thomas Gschwantner $^{2} \cdot$ Klemens Schadauer $^{2} \cdot$ Philippe Lejeune $^{3}$. Jérôme Perin ${ }^{3} \cdot$ Mikhail Pitchugin $^{3} \cdot$ Radim Adolt $^{4} \cdot$ Miroslav Zeman $^{4} \cdot$ Vivian Kvist Johannsen ${ }^{5}$. Sebastian Kepfer-Rojas ${ }^{5}$ - Allan Sims ${ }^{6}$. Claire Bastick $^{7}$. François Morneau ${ }^{8}$ - Antoine Colin ${ }^{7}$. Susann Bender ${ }^{9}$. Pál Kovácsevics ${ }^{10} \cdot$ György Solti $^{10} \cdot$ László Kolozs $^{10} \cdot$ Dóra Nagy $^{10} \cdot$ Kinga Nagy $^{10}$ • Mark Twomey ${ }^{11}$. John Redmond ${ }^{11}$. Patrizia Gasparini ${ }^{12}$ - Monica Notarangelo ${ }^{12}$. Maria Rizzo ${ }^{12} \cdot$ Kristaps Makovskis $^{13}$. Andis Lazdins ${ }^{13}$. Ainars Lupikis ${ }^{13} \cdot$ Gintaras Kulbokas $^{14} \cdot$ Clara Antón-Fernández $^{15}$. Francisco Castro Rego ${ }^{16}$. Leónia Nunes $^{16}$. Gheorghe Marin ${ }^{17}$. Catalin Calota ${ }^{17} \cdot$ Damjan Pantić $^{18} \cdot$ Dragan Borota $^{18} \cdot$ Joerg Roessiger $^{19}$. Michal Bosela ${ }^{19,20}$. Vladimír Šebeň ${ }^{19} \cdot$ Mitja Skudnik $^{21}$ - Patricia Adame ${ }^{22} \cdot$ Iciar Alberdi $^{22} \cdot$ Isabel Cañellas $^{22}$. Torgny Lind ${ }^{23} \cdot$ Renats Trubins ${ }^{24} \cdot$ Esther Thürig $^{25} \cdot$ Golo Stadelmann $^{25} \cdot$ Ben Ditchburn $^{26}$ - David Ross ${ }^{26}$. Justin Gilbert $^{26}$ • Lesley Halsall ${ }^{26}$. Markus Lier ${ }^{1} \cdot$ Tuula Packalen $^{1}$

Published online: 3 September 2019

(C) INRA and Springer-Verlag France SAS, part of Springer Nature 2019

\section{Correction to: Annals of Forest Science}

https://doi.org/10.1007/s13595-019-0863-6

The original article was erroneously published without applying all the provided proof corrections in Section 5 and Table 1. The original article has been updated to render Table 1 and Section 5 correctly. The original article has been corrected.

Publisher's note Springer Nature remains neutral with regard to jurisdictional claims in published maps and institutional affiliations.

Handling Editor: Erwin Dreyer

The online version of the original article can be found at https://doi.org/ 10.1007/s13595-019-0863-6

Jari Vauhkonen

jari.vauhkonen@luke.fi

Extended author information available on the last page of the article 


\section{Affiliations}

Jari Vauhkonen ${ }^{1} \cdot$ Ambros Berger $^{2} \cdot$ Thomas Gschwantner $^{2} \cdot$ Klemens Schadauer $^{2} \cdot$ Philippe Lejeune $^{3}$ - Jérôme Perin ${ }^{3}$. Mikhail Pitchugin $^{3} \cdot$ Radim Adolt ${ }^{4} \cdot$ Miroslav Zeman $^{4} \cdot$ Vivian Kvist Johannsen $^{5} \cdot$ Sebastian Kepfer-Rojas $^{5}$. Allan Sims ${ }^{6} \cdot$ Claire Bastick $^{7} \cdot$ François Morneau $^{8} \cdot$ Antoine Colin $^{7} \cdot$ Susann Bender ${ }^{9} \cdot$ Pál Kovácsevics $^{10}$. György Solti ${ }^{10} \cdot$ László Kolozs $^{10} \cdot$ Dóra Nagy $^{10} \cdot$ Kinga Nagy $^{10} \cdot$ Mark Twomey $^{11} \cdot$ John Redmond ${ }^{11}$. Patrizia Gasparini ${ }^{12}$. Monica Notarangelo ${ }^{12}$ - Maria Rizzo ${ }^{12} \cdot$ Kristaps Makovskis $^{13}$. Andis Lazdins ${ }^{13}$. Ainars Lupikis ${ }^{13}$. Gintaras Kulbokas ${ }^{14}$. Clara Antón-Fernández ${ }^{15}$. Francisco Castro Rego ${ }^{16} \cdot$ Leónia Nunes $^{16}$. Gheorghe Marin ${ }^{17}$. Catalin Calota ${ }^{17}$. Damjan Pantić ${ }^{18}$. Dragan Borota ${ }^{18}$ • Joerg Roessiger ${ }^{19}$. Michal Bosela ${ }^{19,20}$. Vladimír Šebeň ${ }^{19}$ - Mitja Skudnik ${ }^{21}$ • Patricia Adame ${ }^{22}$ • Iciar Alberdi ${ }^{22}$ • Isabel Cañellas ${ }^{22}$ - Torgny Lind $^{23}$. Renats Trubins ${ }^{24}$. Esther Thürig ${ }^{25}$. Golo Stadelmann ${ }^{25}$ • Ben Ditchburn ${ }^{26}$. David Ross ${ }^{26}$ • Justin Gilbert ${ }^{26}$. Lesley Halsall $^{26}$ - Markus Lier ${ }^{1} \cdot$ Tuula Packalen $^{1}$

1 Bioeconomy and Environment Unit, Natural Resources Institute Finland (Luke), Joensuu, Finland

2 Department for Forest Inventory, Federal Research and Training Centre for Forests, Natural Hazards and Landscape, BFW Vienna, Vienna, Austria

3 Forest is life, TERRA Research Unit, Gembloux Agro-Bio Tech, Université de Liège, Gembloux, Belgium

4 Forest Management Institute, Brandýs nad Labem, Czech Republic

5 Department of Geosciences and Natural Resource Management, University of Copenhagen, Frederiksberg C, Denmark

6 Estonian Environment Agency, Tartu, Estonia

7 Institut national de l'information géographique et forestière, pôle national d'expertise sur les ressources forestières,

Champigneulles, France

8 Institut national de l'information géographique et forestière, service de l'inventaire forestier et environnemental, Nogent-sur-

Vernisson, France

9 Thünen Institute of Forest Ecosystems, Eberswalde, Germany

10 National Food Chain Safety Office Forestry Directorate, Frankel Leó utca, Hungary

11 Department of Agriculture, Food and the Marine, Johnstown Castle Estate, Wexford, Ireland

12 CREA - Research Centre for Forestry and Wood, Trento, Italy

13 Latvian State Forest Research Institute "Silava”, Salaspils, Latvia
14 Aleksandras Stulginskis University, Akademija, Lithuania

15 Norwegian Institute of Bioeconomy Research, Ås, Norway

16 Centre for Applied Ecology "Professor Baeta Neves" (CEABN), InBIO, School of Agriculture, University of Lisbon, Lisbon, Portugal

17 National Forest Inventory Department, National Institute for Research and Development in Forestry, Voluntari, Romania

18 The Chair of Forest Management Planning, University of Belgrade, Faculty of Forestry, Belgrade, Serbia

19 National Forest Centre, Zvolen, Slovakia

20 Faculty of Forestry, Technical University in Zvolen, Zvolen, Slovakia

21 Department of Forest and Landscape Planning and Monitoring, Slovenian Forestry Institute, Ljubljana, Slovenia

22 Instituto Nacional de Investigación y Tecnología Agraria y Alimentaria, Madrid, Spain

23 Department of Forest Resource Management, Swedish University of Agriculture Sciences, Umeå, Sweden

24 Southern Swedish Forest Research Centre, Swedish University of Agriculture Sciences, Alnarp, Sweden

25 Swiss Federal Institute for Forest, Snow and Landscape Research WSL, Birmensdorf, Switzerland

26 Inventory and Forecasting, Forest Research, Edinburgh, UK 